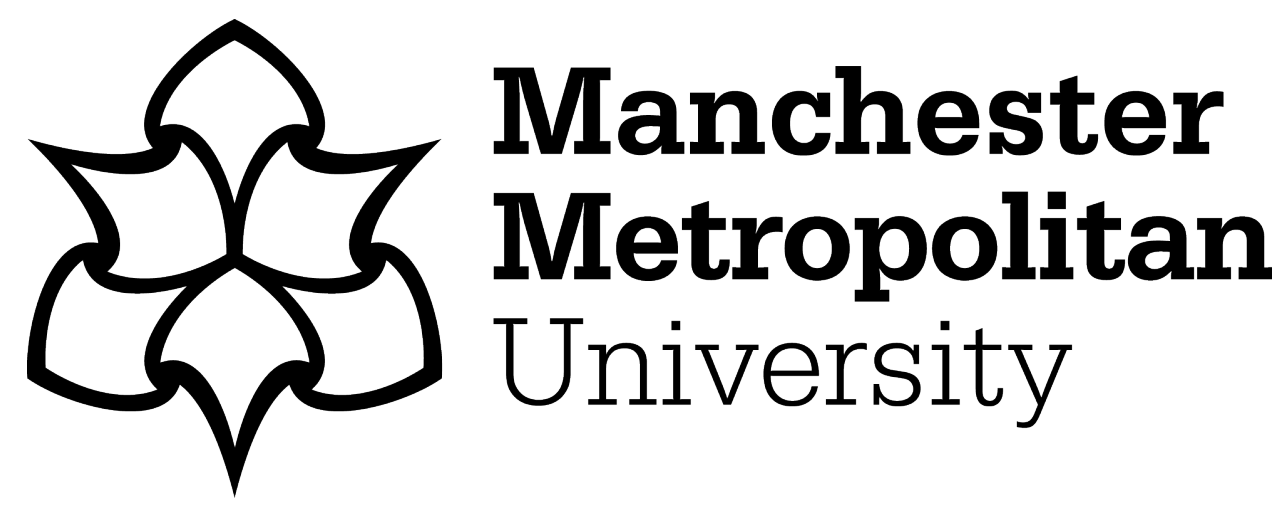

Eseonu, T and Duggan, J ORCID logoORCID: https://orcid.org/0000-00032413-7864 (2022) Negotiating cultural appropriation while re-imagining coproduction via Afrofuturism. Qualitative Research Journal, 22 (1). pp. 96107. ISSN 1443-9883

Downloaded from: https://e-space.mmu.ac.uk/628237/

Version: Accepted Version

Publisher: Emerald Publishing Ltd.

DOI: https://doi.org/10.1108/QRJ-06-2021-0060

Please cite the published version 


\section{Negotiating cultural appropriation while re-imagining co-production via Afrofuturism}

\section{Abstract}

Purpose: We explore the role of claims of cultural appropriation in negotiating who has the right to utilise specific racial, cultural or communities' ways of knowing in research co-production. Cultural appropriation is a claim made against those making illegitimate use of traditions, knowledge and practices that originate from specific racial and/or cultural group. Appropriation helps us interrogate the ways in which rewards and benefits in academia are distributed and shared, denied or hoarded, and by whom.

Design/methodology/approach: The article is a dialogue between two researchers in the in-betweens of research co-production, specifically in the negotiation of claiming the right to lead or engage in Afrofuturist work with communities.

Findings: The claim of cultural appropriation is useful in naming, drawing boundaries and creating spaces for negotiation around access and ownership of academic work but must also develop as part of a broader transformative agenda towards racial equality in academia.

Originality: This is the first article to explore issues of cultural appropriation in research co-production, and co-production in relation to Afrofuturism. This extends ethical concerns on research co-production beyond academic power imbalances with, and extracting value from, communities to negotiating the relationships between academics and traditions, knowledge and practices developed by specific racial and/or cultural groups.

Research implications: In addition to ethical considerations about power imbalances and extractive practices, research co-production should also be concerned with acknowledging and crediting knowledge production practices that originate from specific racial and/or cultural groups.

Keywords: Co-production, cultural appropriation, Afrofuturism, Solidarity 
This dialogue explores the potential of cultural appropriation in negotiating uses of cultural, artistic and intellectual bodies of work created by Black artists, activists and academics specifically Afrofuturism - while co-producing research with young people on possible and preferable futures. The focus emerged when Duggan (White British) proposed using Afrofuturism to make a new digital arts education programme more inclusive for raced and classed students. During the development of this idea, the artists and community groups were from RM communities but the academics involved were White - with the exception of Eseonu (Black British African). Duggan was concerned that as a White man leading this activity, Duggan, was culturally appropriating Afrofuturism. We explore this through a non-traditional format, a dialogue, which refuses to gloss over the non-trivial differences of race, gender and academic position the co-authors share. Our aim is to re-imagine research co-production appropriate to addressing the stark inequalities of a struggling humanity, when due to historical oppression there are too few Racially Minoritised (RM), and especially Black academics, to lead such projects (Bell, et al., 2020) but that RM academics and communities must be or become central to these processes of transformation. First, we define our terms co-production, Afrofuturism and cultural appropriation:

Co-production describes collaborative knowledge production between professionalised researchers (e.g. academics) and the public (e.g. community groups, citizens). Definitions usually include process criteria and/or aims such as empowering participants, democratising research, and realising social justice (e.g. Banks et al., 2018). There are multiple inspirations and traditions in research co-production, of which we illuminate the potential tensions between: One, standpoint theory commitments to grounding and growing research coproduction in-and-from community knowledges, resources, assets and practices (e.g. Enria, 2016). Two, there are many roles and relationships in co-production but positionalities of etic, outsider, animator, catalyst and facilitator are common in supporting non-academics engage in research (Facer and Enright, 2016). These tensions are understood in terms of the inequalities in power and privilege between academics and non-academics while doing research (Beebeejaun et al., 2014). We extend these concerns to ownership and appropriation within academia - between White and Black academics - when working with racial and cultural knowledge and practice traditions (e.g. Afrofuturism).

Afrofuturism describes Black and Afro Diasporic communities' use of speculative and imaginative practices generating 'other stories to tell about culture, technology and things to 
come' (Dery, 1994, p.738). It is a generative focus for re-imagining research co-production because of its diverse, live and lively practices and applications. It is, 'Both an artistic aesthetic and a framework for critical theory, Afrofuturism combines elements of science fiction, historical fiction, speculative fiction, fantasy, Afrocentricity, and magic realism with nonWestern beliefs' (Womack, 2013, p.9). Afrofuturism engages with black radical dreaming to reimagine, reconstitute, re-present and reinvent meaningful black subjectivities. It uses black aesthetics derived from black speculative futurity as Black politics to counter socio-economic inequality and White supremacy (van Veen and Anderson, 2018). We have different motivations and rationales for the shift to Afrofuturism but share the concern for developing research approaches that help raced and classed young people explore things as they are and might be amidst conditions of structural inequality and violence.

Cultural appropriation is an ethical claim at the conjunction of two concerns: 'appropriation' is making private or taking something that you do not own. And, the complex and contested but fundamentally important idea of culture (Young and Brunk, 2009). Within cultural appropriation, Young (2010) distinguishes between subject appropriation (i.e. narratives or characters), object appropriation (i.e. physical objects) and - our focus - content appropriation (i.e. inexhaustible resources such as clothing or music). The wrongs of cultural appropriation are: a moral problem of misappropriating cultural resources and the potential to generate rewards; a cognitive problem threatening a people's cultural authenticity; and an ontological issue threatening a people's capacities for self-representation and cultural production divorced from traditional standards of excellence for managing quality, identity and preventing misrepresentation (Heyd, 2003). It is not unproblematic to find appropriate descriptors for culture - national, racial, ethnic, clan - and we must avoid forms of essentialism that fail to account for culture's complexity, permeability and dynamism (Young, 2010). Without slavery, colonial exploitation, scientific racism and so on, understanding the cultural in cultural appropriation would not be so vexing nor important. We therefore define culture in terms of Black aesthetics and politics to counter histories of oppression including slavery, colonialism and neoliberalism. Afrofuturist aesthetics is intended to 'resist silencing, to resist being co-opted for other agendas that have little to do with black love, black joy, black liberation and freedom, health and wholeness' (Van Veen and Anderson, 2018, p.16). The dialogue develops in three exchanges between Duggan and Eseonu. We conclude that Afrofuturism, as an aesthetics for liberation from oppression, is best thought of as for use by- 
and-for Black communities. This debate of cultural appropriation must be understood, however, in a broader context, both in the advancement of RM academics within academia and a transformative agenda to re-imagine collaborative knowledge production within-andbetween academia and communities.

\section{Eseonu: 1 - The turn to Afrofuturism}

I came across Afrofuturism at the Anticipating Black Futures event hosted at Birmingham City University, in the summer of 2019. It is one of the best spaces I have experienced in terms of how Black scholars accessed, curated and shared Black communities' knowledge. Afrofuturism really resonated with me and I became interested in what it means for coproducing knowledge. During my PhD research, I was exploring employment futures with a group of RM young people. They seemed not to countenance how systemic racial inequities might constrain their prospects. The UK Government's race disparity audit shows that RM young people are less likely to be employed than their White counterparts (Cabinet Office, 2017). This disparity is attributed to structural causes such as living in deprived areas and discrimination (Khattab and Johnston, 2013; Patacchini and Zenou, 2012; Verhaeghe et al., 2013). As is common in doctoral and precarious academic research, this occurred during a one-off research encounter. I faced a dilemma. I could challenge them, using racial literacy approaches to explore how social dynamics and contradictions inherent in being produced as racialised subjects can be negotiated and, as human beings, we are able to exceed such dehumanising constraints (Spivak, 2004, p.526, Stevens et al., 2017, p.460). This could produce insightful data but potentially affect their wellbeing (Bussu et al., 2020). I chose what I felt was the lesser of two ills, accepting their visions of the future.

Now my research agenda focuses on racial justice, co-producing racial literacies with Black communities and using Afrofuturism to re-imagine racially just futures. The chronopolitical aspect of Afrofuturist thought/practice creates a context for co-producing knowledge that encourages processes of disalienation, rejecting deterministic visions of black futures articulated by data, media and capital (Eshun, 2003). I am unsure whether I can call myself an Afrofuturist but, as a Black budding academic seeking to contribute to systemic changes that benefit Black communities, engaging with Black radical dreaming about the possible is how I wish to conduct research.

\section{Duggan: 1 - Something other than an Afrofuturist}


It might seem odd that I planned to re-imagine research co-production through Afrofuturism. I am not nor have I aimed to become an Afrofuturist. I am White British and have no significant cultural connections to Afrofuturist music, art, philosophy and theory. Or, perhaps given the history of cultural appropriation this is not so odd. As it happened I was part of a discussion on increasing student diversity in a new digital arts programme, which aims to educate the region's future digital storytellers. RM people are significantly underrepresented in the digital, arts and creative pipeline and professions (Brook et al., 2018). Increasing diversity is necessary to prevent, for example, the reproduction of probable to inevitable inequality through racist algorithmic governance (Benjamin, 2019a). We understood we needed to problematise 'colour-blind/culturally neutral' approaches to technology and education that normalises Whiteness and Others everyone and everything else (Brock, 2012, p.530). And address, 'the institutional and imaginative underpinnings of oppressive systems' (Benjamin, 2019b, p.3). Rather than integrating or assimilating raced and classed students into higher education, I suggested re-imagining educational spaces through Afrofuturism.

One of the journal reviewers asked, given that Afrofuturism has a reputation for being the reserve of academics and Avant-Garde artists, that I be clear whether this was an academic or community vision. At the time I was thinking less of who owns this idea - again, problematic in relation to cultural appropriation - but rather that this was a particular type idea, set of practices, legacies and inspirations that could create a space to co-produce a response to the lack of institutional diversity in digital arts programmes. I had been involved in an 18-month dialogue with a local theatre collective to make co-production more relevant and transformative to citizens in Hulme, Manchester. The lack of imagination and care in government policy interventions was a stark contrast to the community's rich socio-cultural achievements. We wondered faced with the issue of institutional diversity, What Would Hulme Do?

Looking for inspiration, I - falsely as it turned out - thought that the theatre collective's Christmas Pantomime 'Snow White Privilege' was Afrofuturist because a local artist with an interest in Afrofuturism produced it. This misunderstanding, however, connected with conversations in Manchester about African/ Afro-diasporic pasts, presents and futures, including Afrofuturism, as part of the 75th anniversary of the Pan African Congress hosted in a building in what is now in MMU's campus, adjacent to Hulme. Due to the constraints of the COVID-19 lockdown, the community engagement was more with artists and arts 
organisations rather than young people. There was, however, evidence of a broader vibrancy with young people engaging with Afrofuturism whether the music of Janelle Monáe, the University of the Underground's New Politics and Afrofuturisms course, and a proliferation of ideas and variations (e.g. Afrofuturism 2.0). So, the idea was not owned by either university or community but rather it would create a new territory and set of traditions to explore. If the digital arts programme intended to create the future storytellers of the North West then approaches such as Afrofuturism ought to be included.

\section{Eseonu: 2 - Centring Blackness}

When you shared your proposal, I was excited about the possibilities for developing young people's racial literacy. I had assumed your work was with Black communities. After I found it was not, I felt really uncomfortable putting our original idea out in the world. I knew I had to say something but I was also really conscious about the dynamics between us: You are the more established academic and a White man. I am an early career researcher and a Black woman. Your years of working with issues of justice and knowledge was evident during our conversations so I felt I could challenge you. As I said, I do not claim to be an expert in Afrofuturism, and I have much to learn.

Below is a condensed excerpt of our email exchange where I was making the case for reserving Afrofuturism for use with Black communities and ideally by Black artists:

I hear you when you say that the specifics - alienation/hacking technology can be used by non-Blacks or for non-Blacks. However, my introduction to Afrofuturism and what I have read so far, it does seem to be for Black people by Black people (with the exception of Mark Dery although Alondra Nelson and Kodwo Eshun led the discussions following Mark's coining of the term). When Afrofuturism is discussed by Black people, there is a real sense it is about re-claiming a specific type of oppression: racism. Afrofuturism is a cultural, literary and aesthetic form characterized by the necessity to "bend time" because "imperial historicism" and Western Eurocentric "protocols of institutional memory" (DeLuliis and Lohr in Pillow, 2017, p.134).

I am not familiar with the other types of futurisms (quick google of Marinetti) and I understand why we may want to avoid simply using 'futurist/sm'! I guess this is what Pillow (2017, p.143) was referring:

'While the post-studies scholar may hear the 'futurism' in Afrofuturism as poststructural, to do so would limit Afrofuturism's embodied critique, which 
"posits a reconciliation between an imagined disembodied identity-free future and the embodied identity-specific past and present" (David, 2007, p.697). This reconciliation is necessary due to the prevalence of a "so-called posthuman/post-racial future posited by mostly white futurists" (Anderson, 2015, p.182) where Blackness is erased without ever being acknowledged.'

Afrofuturism centres Blackness.

As I was writing the paper with a White academic, I wondered whether the ethos of Afrofuturism could be utilised in other contexts. The excerpt below is neither a fully developed nor coherent frame of reference:

I would even say that there might be an argument for using ethno-futurisms in critical White studies research where White people are probing complicities etc because it is one way to acknowledge that Whiteness is part of the social construct of race.

In response to your provocation in relation to co-producing research about the practices and rituals, forms of recognition and care, rewards and capitals and who gets them, we cannot ignore how the production of knowledge within universities is structured. Many White scholars have been rewarded and have accumulated performance/progression capital from their research on/with RM communities yet when Black researchers work with racialised communities, they are penalised for it or have to justify the institutional value of their intellectual labour (see Bell et al., 2020; Cooper, 2015). The 'ivory tower' of academic research has been guilty of appropriating and misappropriating practices and rituals from non-White communities (Tuhiwai Smith, 2012). Adebisi (2020) distils the essence of what I was not able to articulate: Afrofuturism is about Black rituals and practices. Those who use Afrofuturism without centring Black communities minimise our abilities and culture. For example, '[Black] people are paid in exposure for their time, their genius... [Black] people are paid a pittance for the cultural practices and artefacts of a people shorn from the origins of those practices' (Adebisi, 2020, n.p.).

I do not wish to see Afrofuturism co-opted and misappropriated by the neoliberal university, which is why my initial reaction was to think that Afrofuturism should remain for Black communities, Black artists and ideally led by Black researchers. However, Black academics are underrepresented in the UK and the pipeline for Black academics is broken (Williams et al., 2019). And, I am reminded of Patricia Hill Collins words, 
Black feminist thought is neither the intellectual property of Black women nor should it be. Rather, seeking out points of convergence with similar projects potentially enriches all parties involved, and certainly exposes how systems of domination work similarly across intersecting power relations (Collins 2016, p.138).

In a similar vein, on reading Waters (2016), I am left with questions of whether the labour of Afrofuturism should be left to Black researchers or does it amount to an abandonment? Is there a patronising assumption that Black researchers will want to co-produce research with an Afrofuturist lens? Perhaps White academics can engage with Afrofuturism if it is in equal partnership with Black communities and artists whilst remaining 'scrupulously vigilant (hyper self-reflexive) in relation to their complicities' in forcing a research agenda on Black communities (Andreotti, 2007, p.75). Therefore, I think Afrofuturism should centre Black communities but I welcome discussions about whether Afrofuturism should be just for Black people and by Black people.

\section{Duggan:2 Afrofuturist worlding}

We agree on the importance of developing appropriate research approaches in relation to social, political and epistemological resources that help raced and classed young people navigate the realities of growing up amidst structural inequalities. In our email exchange you stated it would be acceptable for me to use similar methods and orientations, without claiming the name 'Afrofuturism'. But by that logic instead of working with Afrofuturist speculative fiction, with appropriate reference to Octavia Butler's HistoFuturism (Streeby, 2020, p.72) but not Afrofuturism, I could develop a speculative method focused on retelling pasts, presents and futures without committing cultural appropriation, which obviously remains problematic. I argue for re-imagining co-production in relation to the interrelated transmedia practices, archive of ideas, and the extant communities of Afrofuturism as a whole - even if I am not the one doing it.

Pahl (2016) challenges us to make the university, rather than the community, the imagined Other in research co-production where the academic's gaze into and onto the community is reversed, resisted and re-imagined. I am interested what this means for the relationships between research, methods and young people's lives. We need to unpick the managerialising and neoliberalising research co-production practices: Now we are planning. Now we are collecting data. Now here are seed funds for your projects. As emerged, somewhat ironically, 
from the community consultation: What Would Hulme Do? Janey Riley from the theatre collective explained to me, Hulme was home to Manchester's hip hop scene with its dynamic six elements: MCing, turntablism, b-boying, graffiti, knowledge and hustle - following African cultures oriented around drum, song, dance and art. These orientations create a series of expansive and emergent drives and loops of socio-material practices. The party needs a DJ, music, lights, fliers, a crowd, drinks, marketing, security, recycling and on and on. These are the youth cultures and processes of worlding that we as researchers try so hard to attune to and communicate in research yet arguably absent from our processes of research coproduction.

The proposal was to develop an Afrofuturist Outpost (AO) in the community. Inspired by proven innovations (e.g., 826 Valencia), the AO would provide a space for young people to work with mentors, socialise, make and sell art, volunteer to gain a mix of pastoral support, career development and inspiration as well as co-producing research. The $\mathrm{AO}$ as shop would enable processes of storing and storying, inventory functioning as a research archive for the co-produced artefacts, encounters and objects. It would create an experimental space for (re)valuation (buying, bartering, stealing, collective ownership). Outposts are a staging point in many speculative/Sci-Fi novels where characters come to find things required for an adventure. The young people and the community of Hulme would be invited to bring their collective capacities for imagination, resistance and lived experience to re-imagine new pathways towards emancipatory digital futures. I am aware that for many co-producers this is too prescriptive a proposal. It was just a proposition, a proposal to start things moving. Something to be disassembled into components to seed encounters as the project began, and from there an adventure wherever else it might lead, which in this case became a dialogue on cultural appropriation.

\section{Eseonu: 3 - Inspired by Afrofuturism}

There is no denying the realities of the present and potential impact on the futures of young people, with RM young people more likely to be disproportionately affected. Now and in the years to come, academics will research different communities of young people. What I would say is aesthetics, transmedia practices - art, music fashion, DIY tech, sci-fi storytelling and so forth - are not peculiar to Afrofuturism. Therefore, can be used to work with classed communities to re-imagine futures and possibilities. However, I still maintain that Afrofuturism is peculiar to Black people because of its intersection of Black culture with a 
specific history of oppression of Black people that is still ongoing in the present. Afrofuturism frees racialised communities from 'what Fanon refers to as the yolk of historical and embodied racial epidermal schemata that are utilised by others to define us, and also by us in the service of self-definition' and transcends this a hegemonic construction of racial identities as a constraint (Stevens et al., 2017, p.460). For academics wishing to use Afrofuturism in research with Black communities, it is an antithesis to the research that is built on racism and neoliberalising in existing social contract, economic structures, and history of colonial nation-states (van Veen and Anderson, 2018, p.7) allowing social scientists to think of new possibilities and enter empirical and imaginary evidence into the public sphere and debate our new realities (ibid).

I agree that academics can learn from and be inspired by Afrofuturist praxis in terms of the interrelated transmedia practices, archive of ideas and lives lived to do co-production differently. Nonetheless, it cannot be called Afrofuturism and Afrofuturism should be credited for the inspiration to do research differently. If credit is not given to Afrofuturist praxis, then we are back to the issue of appropriation. However co-production is enacted, communities do not require academia to be the 'saviour of marginality' or a 'benevolent intervention' (Spivak in Andreotti, 2007, p.71). To access knowledge that will be beneficial to the communities academics work with, 'unlearning privilege' will mean that the figure of the academic moves away from being the 'authority and expert' figure. This means,

Working against the grain of our interests and prejudices by contesting the authority of the academy and knowledge centres at the same time that we continue to participate in them and to deploy that authority as teachers, researchers, administrators and theorists (Beverley, in Andreotti, 2007, p.75).

More practically, it means 'stopping oneself from always wanting to correct, teach, theorise, develop, colonise, appropriate, use, record, inscribe, enlighten' (Kapoor, 2004, p.642).

\section{Duggan: 3 - Matters of culture and solidarity}

I want to express my gratitude for your challenge about cultural appropriation. My first reaction though was stuckness. Indeed, this is the claim's performative function: a drawing of a boundary, a policing, a desist! Then I wondered what traditions, resources and ideas I could 
claim. As a White English man, I am historically situated as an apex predator of cultural appropriation. Yet with a working-class background, I often feel bereft of meaningful signifiers of identity and cultural attachment. A colleague, Janet Batsleer, explained my stuckness as being fixed in the hegemonic order of White Patriarchy - a man in air, as it were. Yet this stuckness is also the unrootedness and decontextualization of an ahistorical and asocial subject (me), an achievement of the capitalist project to obliterate non-market relationships, imaginations and desires that have been so important to class-based organisation and resistance (Cowie, 2010; Thompson, 2013). It is this absence of available frames of reference for sense making and consciousness connected to class and race that we have encountered when working with young people.

My engagement with Afrofuturism is driven by what I see is the desperate need for new sources and resources of hope and imagination, finding new forms of sensemaking. The need for the Black Lives Matter \#BLM movement in the present foreshadows the bleak prospect of discountable (Black) lives in a rapidly heating world. The challenge of increasing diversity in a digital arts programme demonstrates the complexity and granularity of these issues. One of the uncomfortable aspects of our dialogue was being called into legacies of oppression and exploitation as an individual (James Duggan) where previously I had only been associated by my identity (White, male, English). It is in relation to this individual-collective continuum that I seek to re-position my practice.

I understood research co-production as imaginative work in relation to an openness to the potentials of events (Duggan, 2020) - which, in this case, was profoundly interrupted by stuckness. I see co-production as the collaborative and imaginative work in conceiving propositions - techniques of relation, ideas and encounters (Manning and Massumi, 2014) then staging them and nurturing our imaginative capacities, 'to answer the cry "It Matters"' (Stengers, 2019, p. 15), as we achieve new thoughts and feelings in a world in process (Gaskill and Nocek, 2014). The approach develops through speculative adventures of thought and a restless appetite towards the eventful movement from diversity and difference into singularity, which is the essence of novelty and innovation (Shaviro, 2009). An eventful approach moved my practice away from emphases on equality and empowerment in coproduction which are no doubt important but, in my experience, insufficient to inform the singularities of practice. At the time, I worried that prioritising novelty, emergence and innovation might obscure young people's voice or presence in the research, which I tried to 
fix through an ethics of the event. I did not consider, however, culture and race within this ethics. The practice involves the continual and often rough-and-ready assembling of diverse media, cultural artefacts, bodies and affects to (co-)produces new ideas, thoughts and feelings. What if this diversity includes Jamaican dancehall music and prints of Hindu deities when no one from those cultures are present? I worry there are resonances with the figure of the colonial adventurer, restless and roaming, dabbling and assembling cultural artefacts all to think and feel something new. Yet, the work of co-productive imagination is to continually work to propose and interpret co-production in new contexts (Whitehead, 1967). The concern therefore becomes developing the imaginative capacities to develop new propositions and means of interpreting what matters in diverse contexts.

Our dialogue has underscored the importance of how these imaginative capacities are being developed and who is practising them. If we accept co-production as a hopeful practice 'within, against and beyond' the neoliberalising present (Bell and Pahl, 2017, p.105), we must interrogate how are interpolated in relation to neoliberalising social practices within the university. Throughout this project I was fixed on how I could respond. This encounter with cultural appropriation has taught me to resist the reduction and abstraction of my possible academic labour - publish, apply for funding - as ways of engaging with social issues. Instead, as Hall $(2018$, p.221) reminds us we ought to commit to,

spaces and temporalities for solidarity actions, as new forms of indignant coproduction against the methodological University, must disrupt the circulation of activity, surplus and privilege that reproduce the University as a node in capitalist reproduction.

Hall goes onto describe various practise open to us in rethinking and disrupting the alienation of our academic labour, presenting alternative values and ways of collectively organising around principles of 'mutual recognition rooted in dignity... [so] academic work can be dissolved into communal and co-operative life.' (pp.220-221) But this must be a critical and collective co-productive imagination. Something we are powerless to achieve as individuals.

\section{Co-production, Afrofuturism and appropriation}

We believe that Afrofuturism presents a profoundly interesting set of ideas, resources and practices to re-imagine research co-production in encounters with young people from RM communities, and the broader institutional context of research. We re-affirm there is an imperative to work with those communities long enduring the stark inequalities of 
imperialism, racism and poverty and disrupt the reproduction of structural forms of oppression in the face of the immanent risks of discountable (Black) lives in a rapidly heating world. One, encounters between academics and young people from RM minoritized communities are potentially overwhelming in negotiating the enormity and severity of past, present and future inequalities, especially in the transient engagements of much early career and arts-based co-produced work. Afrofuturism provides an ecosystem of ideas, practices, critical philosophy and liberatory praxis that challenge the imaginative underpinnings of racial oppression. It provides an archive of imaginative work to the collective situation of oppression to inspire and educate. Two, Afrofuturism provides a coherent framework of philosophical orientations and transmedia practices for re-imagining the institutional context of academic research. Afrofuturism develops a critique of elite, Eurocentric institutions and discourses. Its unique proposition is that we re-imagine a world that did not experience the tragedy of the transatlantic slave trade. We still live with the profound consequences of slavery, whether in terms of colonialism and racism, inequality or the inheritances in management thinking (Rosenthal, 2018). In relation to the magnitude of our struggle to disentangle the effects of the neoliberalisation, managerialisation and acceleration of academia in addition to decolonising the university, methodologies and curricula; re-imagining research coproduction in relation to Afrofuturist lenses and inspirations offers a necessary and invaluable route to developing more affirmative relationships in co-production encounters.

If, as we argue, Afrofuturism presents a considerable resource for re-imagining co-production then what and whose engagements are appropriate, and which are culturally appropriating? It is important to recognise that cultural appropriation is not unproblematic. If academics must remain within their racial, cultural or ethnic group while developing future-oriented practices then the proliferation of ethno-futurisms per ethnicity risks preventing intercultural academic dialogue and reifying racial divisions in perpetuity. There is also a risk of elite capture and epistemic deference where White academics are merely replaced by Black academics, which 'entrenches a politics unbefitting of anyone fighting for freedom rather than for privilege, for collective liberation rather than mere parochial advantage' (Táíwò, 2020 , n.p). These issues are, however, overwhelmed by the motivation not to reproduce the historical legacies of colonialism and racism in the present and futures.

We followed different routes to understanding Afrofuturism's potential for co-producing research, and see our dialogue of indicative of productive ways forward. Claims of cultural 
appropriation ask us to think in more historically and politically nuanced ways than extant values in academic publishing, as the first to make a specific, distinctive contribution to knowledge. Instead, it asks us to attend to the specific ways in which rewards and benefits in academia are distributed and shared, denied or hoarded and by whom. The underrepresentation of RM people in academia makes these issues so significant and timely. In this context, the significance of research co-production to articulate diverse futures with raced and classed communities is that a crucial locus of working with, speculating on (im)possible and (un-)preferable futures is the present, whether as the education of desire (Thompson, 1977) or the material and intellectual construction of these emerging futures. We believe it is possible for academics, artists and activists to work across culture if done with appropriate time, care, negotiation and there is a non-trivial rationale. As with 'blueprint' utopias or fictional works, regardless of its artistry and facility if it fails to prefigure or move towards the conditions for fulfilment then it remains a fiction. And, in this case, would reproduce the harms of structural racism. We must recognise the capture of practices, spaces and jobs for articulating and imagining futures are prominently developed in relation to corporate capitalism (Eshun, 2003). And, the individuals working in these roles are one can assume predominantly White and/or privileged. Duggan, for example, began wondering whether co-production can be re-imagined through Afrofuturism - and of course it can - but in dialogue with Eseonu this became a more sophisticated account of practical considerations of who can do this work, and under what conditions. For Eseonu to lead this publication and continue this academic project avoids abandonment and treads a hopeful path towards a more diverse academia. Ahmed (2017, p.15-16) teaches us to think of citations as, "how we acknowledge our debt to those who came before; those who helped us find our way when the way was obscured because we deviated from the paths we were told to follow.' Citations are bricks building dwellings and by extension new futures, new chains of ideas and scholars connecting and opening diverse futures. This is the very essence of the complex work at the intersection of negotiating our pasts and our futures. We need to find new resources of hope and solidarity as we attempt to articulate and enact a larger, more capacious and collective academic subjectivities, bringing into being an academia more appropriate to the communities in which we work, and more legitimately able to engage with the rich cultural and knowledge resources of RM communities, such as Afrofuturism. 


\section{References}

Adebisi, F. (2020), "The Other Strange Fruit in Ma Rainey's Black Bottom", available at https://folukeafrica.com/the-other-strange-fruit-in-ma-raineys-black-bottom/ (accessed $23^{\text {rd }}$ December 2020).

Ahmed, S. (2017), Living a Feminist Life, Duke University Press, Durham; London.

Andreotti, V. (2007), "An ethical engagement with the other: Spivak's ideas on education", Critical literacy: Theories and practices, Vol. 1, No. 1, pp.69-79.

Banks, S., Hart, A., Pahl, K., \& Ward, P. (2018), "Co-producing research: A community development approach", Banks, S., Hart, A. Pahl, K., \& Ward, P. (Eds.), Co-producing research: A community development approach, Policy Press, Bristol, pp. 1-18.

Beebeejaun, Y., Durose, C., Rees, J., Richardson, J., \& Richardson, L. (2014), “'Beyond text': Exploring ethos and method in co-producing research with communities", Community Development Journal, Vol. 49, No. 1, pp. 37-53.

Bell, D.M \& Pahl, K. (2018), Co-production: towards a utopian approach, International Journal of Social Research Methodology, Vol. 21, No. 1, pp. 105-117.

Bell, M.P., Berry, D., Leopold, J., and Nkomo, S. (2020), "Making Black Lives Matter in academia: A Black feminist call for collective action against anti-blackness in the academy", Gender, Work \& Organization. https://doi.org/10.1177\%2F0149206320968621

Benjamin, R. (2019a), Race after Technology: Abolitionist Tools for the New Jim Code, Polity Press, Cambridge.

Benjamin, R. (2019b), "Introduction: Discriminatory Design, Liberating Imagination", Benjamin R. (Ed.), Captivating technology: race, carceral technoscience, and liberatory imagination in everyday life. Duke University Press, Durham; London, pp. 1-22.

Bhambra, G.K., Gebrial, D. and Nişancıoğlu, K. (2018), "Introduction: Decolonising the University?" In Bhambra, G.K., Gebrial, D. \& Nişancıoğlu, K. (Eds.), Decolonising the University, Pluto Press, London, pp. 1-17.

Bussu, S. Lalani, M. Pattison, S. and Marshall, M. (2020), "Engaging with care: ethical issues in Participatory Research", Qualitative Research, https://doi.org/10.1177/1468794120904883 
Brock, A. (2012), "From the blackhand side: Twitter as a cultural conversation", Journal of Broadcasting \& Electronic Media, Vol. 56, No. 4, pp. 529-549.

Brook, O., O'Brien, D. and Taylor, M. (2018), Panic: Social Class, Taste, and Inequality in the Creative Industries, available from: http://createlondon.org/event/panic-paper/ (accessed 17th February 2021)

Cabinet Office (2017), "Race disparity audit summary findings from the ethnicity facts and figures website", available at: https://www.gov.uk/government/uploads/system/uploads/attachment data/file/680802/R evised RDAEFAF_Feb_18.pdf (accessed 16 February 2018)

Collins, P.H. (2016), "Black Feminist Thought as Oppositional Knowledge", Departures in Critical Qualitative Research, Vol. 5, No. 3, pp.133-144.

Cooper, B.C. (2015), "Love No Limit: Towards a Black Feminist Future (In Theory)", The Black Scholar, Vol. 45, No. 4, pp.7-21.

Cowie, J. (2010), Old Fashioned Heroes of the New Working Class in Stayin' Alive: The 1970s and the Last Days of the Working Class, The New Press, New York; London.

Dery, M. (1994), Flame Wars: The Discourse of Cyberculture. Duke University Press, Durham, NC; London.

Duggan, J.R. (2020), "The co-productive imagination: a creative, speculative and eventful approach to co-producing research", International Journal of Social Research Methodology, https://doi.org/10.1080/13645579.2020.1799638

Enria, L. (2016), "Co-producing knowledge through participatory theatre: reflections on ethnography, empathy and power", Qualitative Research, Vol. 16, No. 3, pp. 319-329.

Eshun, K. (2003), "Further Considerations on Afrofuturism", CR: The New Centennial Review, Vol. 3, No. 2, pp. 287-302.

Facer, K., and Enright, B. (2016), Creating living knowledge: The connected communities programme, community university relationships and the participatory turn in the production of knowledge, University of Bristol/AHRC Connected Communities, Bristol.

Enright, B., Facer, K., and Larner, W. (2016), "Reframing co-production: Gender, relational academic labour and the university", Jupp, E. Pykett, J. \& Smith, F.M. (Eds.), Emotional states: Sites and spaces of affective governance, Taylor \& Francis Group, Oxford, pp. 36-51. Gaskill, N. and Nocek, A.J. (2014), “An adventure of thought”, Gaskill, N. \& Nocek, A.J. (Eds.), The Lure of Whitehead, University of Minnesota Press, Minneapolis; London, pp. 1-41. 
Hall, R. (2018), The Alienated Academic: The Struggle for Autonomy Inside the University, Palgrave Macmillan, London.

Heyd, T. (2003), "Rock Art Aesthetics and Cultural Appropriation", Journal of Aesthetics and Art Criticism, 61, pp. 37-46.

Kapoor, I. (2004), “Hyper-self-reflexive development? Spivak on representing the Third World 'Other'", Third World Quarterly, Vol. 4, No. 25, pp. 627-47.

Khattab, N., and Johnston, R. (2013), "Ethnic and religious penalties in a changing British labour market from 2002 to 2010: the case of unemployment", Environment and Planning A, Vol. 45, No.6, pp. 1358-1371.

Manning, E. and Massumi, B. (2014), Thought in the act: Passages in the ecology of experience, University of Minnesota Press, Minneapolis; London.

Pahl, K. (2016), "The University as the 'Imagined Other' Making Sense of Community CoProduced Literacy Research", Collaborative Anthropologies, Vol. 8, No. 1-2, pp. 129-148.

Patacchini, E. and Zenou, Y. (2012), "Ethnic networks and employment outcomes", Regional Science and Urban Economics, Vol. 42, No. 6, pp.938-949.

Pillow, W.S. (2017), "Imagining policy [data] differently", Parker, S., Gulson, K. N., \& Gale, T (Eds.), Policy and inequality in education, Springer, Singapore, pp. 133-151.

Rosenthal, C. (2018), Accounting for Slavery: Masters and Management, Harvard University Press, Cambridge, Ma.; London.

Shaviro, S. (2009), Without criteria: Kant, Whitehead, Deleuze, and Aesthetics, MIT Press. Cambridge, Ma.; London:

Smith, L.T. (2012), Decolonizing methodologies: research and indigenous peoples, (2nd Ed.) Zed Books, London:

Spivak, G. (2004), "Righting wrongs", The South Atlantic Quarterly, Vol. 03, No. 2/3, pp. 523581.

Stengers, I. (2019), "Putting Problematization to the test of our present", Theory, Culture \& Society, OnlineFirst. https://doi.org/10.1177/0263276419848061

Stevens, G., Bell, D., Sonn, C.C., Canham, H. and Clennon, O. (2017), "Transnational perspectives on Black subjectivity", South African Journal of Psychology, Vol. 47, No.4, pp.459469. https://doi.org/10.1177/0081246317737929

Streeby, S. (2020), Imagining the Future of Climate Change: World-Making Through Science Fiction and Activism, University of California Press, Oakland, California: 
Táíwò, O.O. (2020), "Being-in-the-Room Privilege: Elite Capture and Epistemic Deference", The Philosopher, Vol. 108, No. 4. available online: https://www.thephilosopher1923.org/essay-taiwo (accessed 15th January 2021) Thompson, E.P. (1977), William Morris: Romantic to Revolutionary, Merlin, London: Thompson, E.P. (2013), The Making of the English Working Class, Penguin Modern Classics, London.

van Veen, T.C. and Anderson, R., (2018), “Future Movements: Black Lives, Black Politics, Black Futures-An Introduction", Topia: Canadian Journal of Cultural Studies, pp. 5-21. https://doi.org/10.3138/topia.39.00

Verhaeghe, P.P., Li, Y., and Van de Putte, B. (2013), "Socio-economic and ethnic inequalities in social capital from the family among labour market entrants", European Sociological Review, Vol. 29, No. 4, pp.683-694.

Waters, K. (2016), "A Journey from Willful Ignorance to Liberal Guilt to Black Feminist Thought", Departures in Critical Qualitative Research, Vol. 5. No. 3, pp.108-115. https://doi.org/10.1525/dcqr.2016.5.3.108

Whitehead, A. N. (1967), Science and the modern world, The Free Press, New York.

Williams, P., Bath, S., Arday, J. and Lewis, C. (2019), "The Broken Pipeline - Barriers to Black PhD Students Accessing Research Council Funding", available at https://leadingroutes.org/mdocs-posts/the-broken-pipeline-barriers-to-black-studentsaccessing-research-council-funding (accessed 25th September, 2019).

Womack, Y.L. (2013), Afrofuturism: The World of Black Sci-Fi and Fantasy Culture, Chicago Review Press, Chicago.

Young, J.O. and Brunk, C.G. (2009), "Introduction", Young J.O. \& Brunk C.G. (Eds.), The Ethics of Cultural Appropriation, Wiley-Blackwell, Malden, MA; Oxford; Chichester, West Sussex: pp.1-10.

Young, J.O. (2010), Cultural Appropriation and the Arts, Blackwell Publishing, Malden, MA; Oxford; Victoria, Australia: 